\title{
Characterization of a Pseudomonas aeruginosa Transposon Insertion Mutant with Defective Release of Exoenzymes
}

\author{
By VIVEKA LINDGREN ${ }^{1 *}$ AND BENGT WRETLIND ${ }^{2}$ \\ ${ }^{1}$ Department of Clinical Microbiology, Karolinska Hospital, S-10401 Stockholm, Sweden \\ ${ }^{2}$ Department of Clinical Bacteriology, Danderyd Hospital, S-18288 Danderyd, Sweden
}

(Received 14 July 1986; revised 3 October 1986)

\begin{abstract}
A Pseudomonas aeruginosa transposon insertion mutant with defective release of several exoenzymes has been characterized. The Tn5-751 insertion mutation was located in the previously described $x c p-1$ locus at 0 min on the chromosomal map and caused several exoenzymes to remain in cell-bound form. At least one of the exoenzymes, elastase, was accumulated in the periplasmic space. The periplasmic elastase had the same $M_{\mathrm{r}}$ as the extracellular enzyme produced by the wild-type strain. The virulence of the mutant was comparable to that of wild-type strains in experimental burn infection in mice. The presence of an easily selectable antibiotic resistance marker in the $x c p-1$ locus offers the possibility of cloning the gene(s) involved in exoprotein secretion.
\end{abstract}

\section{INTRODUCTION}

Pseudomonas aeruginosa possesses machinery for the efficient release of exoproteins and is of interest as a host for cloned genes coding for exported products. Six genetic loci $(x c p)$ involved in the synthesis or release of exoproteins have been described in $P$. aeruginosa (Wretlind \& Pavlovskis, 1984). Mutations in these $x c p$ loci cause pleiotropic effects with reduced activities of several exoenzymes. In some of the Xcp mutant classes ( $x c p-1, x c p-5$ and $x c p-6)$ exoproteins are synthesized but are not exported efficiently, indicating that the corresponding loci control some steps in the transport machinery. In order to study the mechanism of protein export further in $P$. aeruginosa we have isolated transposon insertion mutations in those $x c p$ loci that affect exoprotein release. In the present work the genetic and enzymic characterization of a mutant with a transposon insertion in the $x c p-l$ locus is presented. We have also studied the effect of this mutation on virulence since roles for exotoxin A and elastase in certain types of Pseudomonas infections have been postulated (Lui, 1974; Pavlovskis \& Wretlind, 1979; Woods \& Iglewski, 1983; Wretlind \& Pavlovskis, 1983).

\section{METHODS}

Bacterial strains, plasmids and bacteriophage. The bacterial strains, plasmids and bacteriophage used in this study are listed in Table 1. The insertion mutation was isolated as an elastase deficient mutant after transposon mutagenesis with Tn5-751 (Haas et al., 1984) and transferred to the prototrophic strain PAOl by transduction. The resulting transductant PAO6204 was protease-negative on skimmed milk agar and exhibited resistance to kanamycin and trimethoprim (Haas et al., 1984). Strain PAO6204 was compared to strain PAO6202 by doing enzyme assays and virulence tests. In strain PAO6202 Tn5-751 is inserted into a hyu (hydroxyproline utilization) locus, but otherwise the two strains are isogenic.

Media and growth conditions. For the assays of enzyme activities and for the identification of enzyme antigens the following media were used: $(a)$ minimal medium of Davis \& Mingioli (1950) supplemented with glucose $\left(5 \mathrm{~g} \mathrm{l}^{-1}\right)$ and yeast extract $\left(2 \mathrm{~g}^{-1}\right)(\mathrm{MYG})$ for the assay of alkaline proteinase (EC 3.4.24.4); (b) MYG medium

Abbreviations: G6PD, glucose-6-phosphate dehydrogenase. 


\section{Table 1. Bacterial strains, plasmids and bacteriophage used in this study}

For genetic symbols see Holloway et al. (1979) and Holloway \& Matsumoto (1984).

Genotype or phenotype and approx.
map position of relevant markers

$P$. aeruginosa strains

POA1

PAO25

PAO236

PAO6202

PAO6204

PAO7520

KS904

Plasmids

FP2

R68.45

Bacteriophage

E79tv2

\author{
Prototroph, chl-2 \\ argF10 leu-10 \\ ilv-226 (7 min) his-4 (15 min) \\ lys -12 met-28 trp-6 proA82 nalA \\ hyu::Tn5-751 \\ $x c p:$ : Tns-751 \\ pur-67 (90 $\mathrm{min})$ cys-59 (93 $\mathrm{min})$ \\ proB $(2 \mathrm{~min}) \mathrm{Str}^{\mathrm{R}}$ \\ ilv-226 his-4 lys-12 met-28 \\ trp-6 proA82 xcp-1 (0 min)
}

$\mathrm{Hg}$ Tra Cma IncP-8

$\mathrm{Cb} \mathrm{Nm} / \mathrm{Km}^{\mathrm{R}} \mathrm{Tc}^{\mathrm{R}}$ Tra Cma IncP-1

General transducing phage
Reference

Holloway et al. (1979)

Haas \& Holloway (1976)

Haas \& Holloway (1976)

Haas et al. (1984)

Haas et al. (1984)

Streptomycin resistant mutant of

PAO6020 (Soldati et al., 1984)

Wretlind \& Pavlovskis (1984)

Pemberton \& Holloway (1972)

Haas \& Holloway (1976)

Morgan (1979)

supplemented with Casamino acids $\left(10 \mathrm{~g}^{-1}\right)(\mathrm{MCYG})$ for the assays of elastase (EC 3.4.24.4) and staphylolytic enzyme; (c) phosphate deficient medium according to Torriani (1968) for the assay of alkaline phosphatase (EC 3.1.3.1); (d) MYG medium supplemented with tryptone $\left(5 \mathrm{~g} \mathrm{l}^{-1}\right)$ for the assay of lipase (EC 3.1.1.3); and (e) dialysed tryptic soy broth supplemented with $5 \mathrm{~mm}$-nitrilotriacetate and glycerol $\left(10 \mathrm{~g}^{-1}\right)$ for the assay of exotoxin A. The strains were grown in baffled shaking flasks at $37^{\circ} \mathrm{C}$ for media $(a)-(d)$ and at $30^{\circ} \mathrm{C}$ for medium $(e)$ (Wretlind \& Pavlovskis, 1984; Björklind et al., 1985). Enzyme activities were assayed in overnight cultures since the extracellular levels of the different exoenzymes were then found to be maximum in cultures of wild-type bacteria. There were no significant differences in growth yield between the mutants and strain PAO1. The two strains were cultured at the same time and the enzyme assays were then done in parallel.

Genetic techniques. Recombinants were selected on agar plates with the minimal medium of Davis \& Mingioli (1950) supplemented with glucose and appopriate growth factors. Trimethoprim resistance $\left(\mathrm{Tp}^{\mathrm{R}}\right)$ was scored on nutrient agar supplemented with $500 \mu \mathrm{g}$ trimethoprim $\mathrm{ml}^{-1}$.

The isolation of the mutant strain PAO6204 by transposon insertion mutagenesis has been described previously (Haas et al., 1984). Conjugational crosses with the Escherichia coli strain ED8654 (pME9) and the $P$. aeruginosa strain PAO6049 were performed and the transposon phenotype $\left(\mathrm{Km}^{\mathrm{R}} \mathrm{Tp}^{\mathrm{R}}\right)$ was selected for at $43^{\circ} \mathrm{C}$. The donor was counterselected with streptomycin. After purification of the $\mathrm{Km}^{\mathrm{R}} \mathrm{Tp}^{\mathrm{R}} \mathrm{Str}^{\mathrm{R}}$ recombinants it was confirmed that they were sensitive to carbenicillin and tetracycline, i.e. that the vector plasmid was no longer present. The recombinants were then screened for elastase activity on elastin agar plates. One elastase deficient mutant was found among 2500 recombinants carrying the Tn-5-751 transposon from pME9. The transposon insertion mutation causing the elastase deficient phenotype was subsequently transferred to strain PAO1 by transduction and one of three tested transductants had the exoprotein deficient phenotype (Xcp ${ }^{-}$) (Haas et al., 1984). This transductant (PAO6204) was used in the present study.

Conjugational crosses for mapping of the transposon mutation were done by the membrane filter mating technique (Curtis, 1982). Since strain PAO6204 is prototrophic it was counterselected with streptomycin or nalidixic acid $\left(1 \mathrm{mg} \mathrm{ml}^{-1}\right)$ when used as a donor in conjugation. Transduction was done as described previously (Haas et al., 1977; Wretlind \& Pavlovskis, 1984). All recombinants were purified once by picking them onto the same medium as they had been selected on, before scoring for unselected markers. The Xcp phenotype was scored on tryptic soy agar supplemented with $15 \%(\mathrm{w} / \mathrm{v})$ skimmed milk.

Fractionation of cells. Cell-bound enzyme activities (Table 2) were measured in cell pellets that had been washed once with $0.9 \% \mathrm{NaCl}$ and then disintegrated by ultrasonic treatment. Spheroplast preparation and shocking procedure were essentially according to the methods of Cheng et al. (1971). The cells in a $50 \mathrm{ml}$ overnight culture were washed once with $50 \mathrm{ml} 0.01 \mathrm{M}-\mathrm{Tris} / \mathrm{HCl}\left(\mathrm{pH} \mathrm{7.5)}\right.$ and resuspended in $0.2 \mathrm{M}-\mathrm{MgCl}_{2}, 0.01 \mathrm{M}-\mathrm{Tris} / \mathrm{HCl}$ (pH 8.4), lysozyme $\left(500 \mu \mathrm{g} \mathrm{ml}^{-1}\right)$. After incubation for $30 \mathrm{~min}$ in a $25^{\circ} \mathrm{C}$ water bath shaker the cells were centrifuged $(13000 \mathrm{~g}, 15 \mathrm{~min})$, resuspended in cold $0.01 \mathrm{M}-\mathrm{MgCl}_{2}, 0.01 \mathrm{M}$ - Tris/ $\mathrm{HCl}(\mathrm{pH} 8.4)$ and incubated at $4{ }^{\circ} \mathrm{C}$ for $15 \mathrm{~min}$. During this incubation the majority of the cells became spherical. These spheroplasts were centrifuged $(13000 \mathrm{~g}, 15 \mathrm{~min})$, resuspended in cold $0.2 \mathrm{M}-\mathrm{MgCl}_{2}, 0.01 \mathrm{M}-\mathrm{Tris} / \mathrm{HCl}(\mathrm{pH} 8.4)$ and again incubated at $4{ }^{\circ} \mathrm{C}$ for 
$15 \mathrm{~min}$. Finally, the spheroplasts were centrifuged and resuspended in $0.01 \mathrm{M}-\mathrm{Tris} / \mathrm{HCl}(\mathrm{pH} 7 \cdot 5$ ). They were then sonicated and the membrane fraction was pelleted by centrifugation at $105000 \mathrm{~g}$ for $60 \mathrm{~min}$. During the whole procedure samples were taken from the supernatants and the membrane fraction for assays of elastase and glucose6-phosphate dehydrogenase (G6PD, EC 1.1.1.49) activities. Elastase activity was not inhibited by any of the $\mathrm{MgCl}_{2}$ concentrations used in the shock fluids, while G6PD activity was inhibited by $0 \cdot 2 \mathrm{M}-\mathrm{MgCl}_{2}$ but not by $0.01 \mathrm{M}$.

Enzyme assays. Proteinase activity was measured by a caseinolytic method with azocasein as substrate (Kreger \& Gray, 1978) [one unit of enzyme activity (U) corresponds to an increase in $A_{440}$ of $0 \cdot 1 \mathrm{~min}^{-1}$ ]. Since the cells were grown in MCYG broth in which little or no alkaline proteinase is formed by wild-type cells, the assay predominantly measures the elastase activity (Jensen et al., 1980a, Pavlovskis \& Wretlind, 1982). Lipase activity was assayed with p-nitrophenyl caprylate as substrate (Wretlind et al., 1977) and alkaline phosphatase activity was assayed with $p$-nitrophenyl phosphate as substrate (Torriani, 1968) (for both assays $1 \mathrm{U}$ causes the hydrolysis of $1 \mu \mathrm{mol}$ substrate $\left.\min ^{-1}\right)$. Staphylolytic enzyme activity was measured as lysis of a suspension of Staphylococcus aureus Copenhagen at $25^{\circ} \mathrm{C}$ (Wretlind et al., 1977) (1 U corresponds to a decrease in $A_{650}$ of $1.0 \mathrm{~min}^{-1}$ ). Alkaline proteinase and exotoxin $A$ in cell culture supernatants were assayed by rocket immunoelectrophoresis against rabbit antisera (Laurell, 1966; Björklind et al., 1985). G6PD activity was assayed as described by Malamy \& Horecker (1964) (1 U causes the reduction of $1 \mu \mathrm{mol}$ NADP $\min ^{-1}$ ). Elastase assays were done twice on culture supernatants and ultrasonic treated cells. The other enzymes were tested once. Although the absolute elastase activity showed a significant variation between experiments, the relative amounts of cell-bound and extracellular activities always showed the same pattern, i.e. no cell-bound forms of exoenzymes could be detected in the wildtype strain under the experimental conditions used here, while the mutant had more than $50 \%$ of the total activities of several exoenzymes cell-bound.

SDS-PAGE and immunoblotting. Cells grown in MCYG were washed once with $0.9 \%$ saline and disintegrated by ultrasonic treatment. Supernatants from the same cell cultures were concentrated about 20 -fold by dialysis against polyethylene glycol 20M. After boiling in SDS-buffer according to Neville (1971), samples of cells, supernatants and an elastase standard were electrophoresed through a stacking gel (6\%, polyacrylamide) and a gradient resolving gel $(7 \cdot 5-15 \%, \mathrm{w} / \mathrm{v}$, polyacrylamide) with the buffer system of Neville (1971). In each experiment two gels were run with the same samples. One gel was stained with Coomassie Brilliant Blue while the separated proteins on the other gel were transferred to a nitrocellulose sheet and submitted to immunoblotting essentially as described by Towbin et al. (1979). Elastase antiserum for the immunoblotting procedure was prepared by immunizing rabbits with $P$. aeruginosa elastase as described previously (Pavlovskis \& Wretlind, 1979). The detecting probe in the immunoblotting procedure was horse-radish peroxidase substrate used according to the directions of the producer.

Virulence tests. The bacteria were grown in Brain Heart Infusion broth. They were harvested in the exponential phase of growth, washed once with PBS $\left(0.18 \mathrm{M}-\mathrm{NaCl}, 0.0036 \mathrm{M}-\mathrm{KCl}, 0.0086 \mathrm{M}-\mathrm{Na}_{2} \mathrm{HPO}_{4}, 0.0020 \mathrm{M}-\mathrm{KH}_{2} \mathrm{PO}_{4}\right.$, pH 7.4) and then suspended in PBS to approximately $4 \times 10^{8}$ c.f.u. $\mathrm{ml}^{-1}$. From this suspension serial 10-fold dilutions were prepared and inoculated subcutaneously into mice according to the burned mouse model of Stieritz \& Holder (1975).

Chemicals. Azocasein, p-nitrophenyl caprylate, p-nitrophenyl phosphate, glucose 6-phosphate and NADP were from Sigma; $P$. aeruginosa exotoxin A was from the Swiss Serum and Vaccine Institute, Berne, Switzerland; $P$. aeruginosa alkaline proteinase and elastase were from Nagase Biochemicals, Kyoto, Japan; and horse-radish peroxidase, conjugated $S$. aureus protein $\mathrm{A}$ and peroxidase substrate were from Bio-Rad.

\section{RESULTS}

\section{Biochemical characterization of strain PAO6204}

The mutant strain PAO6204 could not efficiently export elastase, lipase, alkaline phosphatase, staphylolytic enzyme or exotoxin A out of the cells. Instead these enzymes were accumulated in cell-bound form (Table 2). Alkaline proteinase was the only exoenzyme which we have found extracellularly in similar amounts as the wild-type strain (Table 2). Thus, phenotypically, strain PAO6204 resembled the previously described exoprotein deficient mutants KS904 ( $x c p-1)$ and KS902 (xcp-5) (Wretlind \& Pavlovskis, 1984).

The localization in the mutant cells of one of the exoproteins, namely elastase, was further investigated by osmotic shocking of the cells and subsequent disruption by sonication. The major part of the elastase activity was found in the shock fluids. Periplasmic proteins are selectively released by such a shock procedure (Cheng et al., 1971). G6PD was used as an intracellular marker. The activity of this enzyme was inhibited by $0.2 \mathrm{M}-\mathrm{MgCl}_{2}$ and therefore could be assayed validly only in the membrane fraction, the cell lysate and the $0.01 \mathrm{M}-\mathrm{MgCl}_{2}$ 
Table 2. Localization of exoenzymes in strains PAO6202 (xcp $\left.{ }^{+}\right)$and PAO6204 (xcp : :Tn5-751)

Enzyme activities are given as $\mathrm{U} \mathrm{ml}^{-1}$ except alkaline protease $\left(\mu \mathrm{g} \mathrm{ml}^{-1}\right)$ and exotoxin $\mathrm{A}\left(\mathrm{ng} \mathrm{ml}^{-1}\right)$. EC, extracellular activity; CB, cell-bound activity.

\begin{tabular}{|c|c|c|c|c|c|c|c|c|c|c|c|c|}
\hline \multirow[b]{2}{*}{ Strain } & \multicolumn{2}{|c|}{ Elastase } & \multicolumn{2}{|c|}{ Lipase } & \multicolumn{2}{|c|}{$\begin{array}{c}\text { Alkaline } \\
\text { phosphatase }\end{array}$} & \multicolumn{2}{|c|}{$\begin{array}{l}\text { Staphylolytic } \\
\text { enzyme }\end{array}$} & \multicolumn{2}{|c|}{ Exotoxin A } & \multicolumn{2}{|c|}{$\begin{array}{l}\text { Alkaline } \\
\text { proteinase }\end{array}$} \\
\hline & EC & CB & $\mathrm{EC}$ & CB & $\mathrm{EC}$ & $\mathrm{CB}$ & $\mathrm{EC}$ & $\mathrm{CB}$ & $\mathrm{EC}$ & CB & $\mathrm{EC}$ & CB \\
\hline $\begin{array}{l}\text { PAO6202 } \\
\text { PAO6204 }\end{array}$ & $\begin{array}{l}2 \cdot 0 \\
0.5\end{array}$ & $\begin{array}{l}0 \\
1.7\end{array}$ & $\begin{array}{r}670 \\
67\end{array}$ & $\begin{array}{l}165 \\
224\end{array}$ & $\begin{array}{r}180 \\
36\end{array}$ & $\begin{array}{l}113 \\
960\end{array}$ & $\begin{array}{l}2 \cdot 2 \\
0 \cdot 1\end{array}$ & $\begin{array}{l}0 \cdot 1 \\
3 \cdot 5\end{array}$ & $\begin{array}{r}400 \\
0\end{array}$ & $\begin{array}{l}\text { ND } \\
\text { ND }\end{array}$ & $\begin{array}{l}11 \\
10\end{array}$ & $\begin{array}{l}\text { ND } \\
\text { ND }\end{array}$ \\
\hline
\end{tabular}

ND, Not done.

Table 3. Localization of elastase and G6PD

Enzyme activities are given as percentages of total activity. Total elastase activity was $2.0 \mathrm{U} \mathrm{ml}^{-1}$ for PAO6202 and 2.4 $\mathrm{U} \mathrm{ml}^{-1}$ for PAO6204. Total G6PD activity was $0.171 \mathrm{U} \mathrm{ml}^{-1}$ for PAO6202 and $0.032 \mathrm{U} \mathrm{ml}^{-1}$ for PAO6204.

\begin{tabular}{|c|c|c|c|c|}
\hline & \multicolumn{2}{|c|}{ Elastase } & \multicolumn{2}{|c|}{ G6PD } \\
\hline & PAO6202 & PAO6204 & PAO6202 & PAO6204 \\
\hline Culture supernatant & $>99.5$ & 23 & 0 & 0 \\
\hline $0 \cdot 2 \mathrm{M}-\mathrm{MgCl}_{2} /$ lysozyme & 0 & 7 & ND & ND \\
\hline $0.01 \mathrm{M}-\mathrm{MgCl}_{2}$ & 0 & 34 & 0 & 3 \\
\hline $0.2 \mathrm{M}-\mathrm{MgCl}_{2}$ & 0 & 20 & ND & ND \\
\hline Membrane fraction of spheroplasts & 0 & $<0.5$ & 3 & 0 \\
\hline Cell-free lysate & $<0.5$ & 16 & 97 & 97 \\
\hline
\end{tabular}

ND, Not done.

shock fluid. Since no G6PD activity was found in the $0.01 \mathrm{M}-\mathrm{MgCl}_{2}$ shock fluid, we concluded that there was no extensive cell lysis during the spheroplast formation procedure (Table 3). G6PD activity in the cell lysate of PAO6204 was significantly lower than that of PAO6202 (Table 3). When equal amounts of cell lysate from PAO6202 and PAO6204 were mixed and G6PD activity then assayed, the PAO6202 activity was reduced more than fivefold (data not shown). We suggest that this reduction was due to digestion of G6PD by protease(s) present in the cell lysate from PAO6204, probably as a contamination from the shock fluids (Table 3). From the above experiments we concluded that elastase and probably also the other cell-bound exoproteins were located in the periplasmic space of the mutant cells.

In another mutant (PAKS-18) isolated in our laboratory an inactive elastase precursor is accumulated in the periplasmic space (Wretlind et al., 1977; Fecycz \& Campbell, 1985). The precursor can be activated by several proteases, including elastase, or by incubation of the sonicated cells at $37^{\circ} \mathrm{C}$. No further activation of elastase could be demonstrated in strain PAO6204 (data not shown).

Exoproteins are generally formed as larger precursors from which the $\mathrm{NH}_{2}$-terminal signal sequence is cleaved during the transport process (for a review see Silhavy et al., 1983). We therefore compared the molecular size of the cell-bound elastase from strain PAO6204 with that of extracellular elastase from strain PAO6202. The enzymes were analysed by SDS-PAGE combined with immunoblotting. No difference between the elastases from the two strains was found (data not shown).

\section{Mapping of the insertion mutation in strain PAO6204}

Conjugational crosses mediated by the plasmids R68.45 and FP2, respectively, were done with strain PAO6204 as a donor and different auxotrophic strains as recipients. Significant linkage was found between the $x c p::$ Tn $5-751$ mutation and the $i l v-226$, his-4, proB and cys-59 markers (Table 4). Segregation of trimethoprim resistance (due to the Tn5-751 insertion) among the $\mathrm{Pro}^{+}$recombinants was controlled in the cross between PAO6204(R68.45) and PAO7520. 
Table 4. Conjugational analysis of the xcp::Tn5-751 mutation

Donor strains were PAO6204(R68.45) and PAO6204(FP2), respectively. Recipient strains were PAO236 and PAO7520.

$\begin{array}{lcc}\text { Selected marker } & \overbrace{\text { Donor R68.45 }}^{\text {Percentage of Xcp- recombinants }} & \text { Donor FP2 } \\ \text { ilv-226 (7 min) his-4 }(15 \mathrm{~min}) & 61 & 36 \\ \text { proB }(2 \mathrm{~min}) & 90 & 55 \\ \text { cys-59 }(93 \mathrm{~min}) & 93 & 65 \\ \text { pur-67 }(90 \mathrm{~min}) & 7 & \text { ND }\end{array}$

ND, Not done.

All the $\mathrm{Xcp}^{-}$recombinants were resistant to trimethoprim while all the $\mathrm{Xcp}^{+}$recombinants were sensitive. Thus, trimethoprim resistance segregated together with the $\mathrm{Xcp}^{-}$phenotype, indicating that this phenotype of strain PAO6204 was caused by the insertion of Tn5-751. In transductional crosses mediated by phage E79tv2 no linkage was found between the $x c p$ insertion mutation and proB or cys-59 markers (data not shown).

The mapping data from the conjugational crosses indicated that the $x c p:: \operatorname{Tn} 5-751$ mutation was located in the same region as the previously described $x c p-1$ mutation near 0 min on the chromosomal map (Wretlind \& Pavlovskis, 1984). In order to confirm the close vicinity between the $x c p:: \operatorname{Tn} 5-751$ and $x c p-1$ mutations, we did two R68.45 mediated crosses with strain KS904 as recipient and with strains PAO6204 and PAO25, respectively, as donors. Ilv $^{+}$recombinants were selected for and the frequency of $\mathrm{Xcp}^{+}$was then scored. In the cross with PAO25 (which is $\mathrm{Xcp}^{+}$) as a donor the co-transfer frequency of $\mathrm{Xcp}^{+}$was $58 \%$. When strain PAO6204 was used as a donor no $\mathrm{Xcp}^{+}$recombinants could be found among 199 scored $\mathrm{Ilv}^{+}$exconjugants. We concluded that $x c p-1$ (in strain KS904) and $x c p:: T n 5-751$ are located close to each other in the same gene and thus recombination between the two mutations is prevented or is a very rare event.

\section{Virulence of the xcp transposon insertion mutant}

Virulence of strains PAO6202 and PAO6204 was compared using the burned mouse model (Stieritz \& Holder, 1975; Pavlovskis \& Wretlind, 1979). No significant difference between LD $_{50}$ values for the two strains was found in three separate experiments (data not shown).

\section{DISCUSSION}

We have studied a transposon insertion mutation in $P$. aeruginosa causing defective release of several exoenzymes. The mutation is located in the previously described $x c p-1$ locus. The results of this study indicate that the exoenzymes accumulate in the periplasmic space of the mutant cells. In both wild-type and mutants of certain strains of $P$. aeruginosa an inactive elastase precursor, with the same $M_{\mathrm{r}}$ as mature elastase, has been demonstrated in the periplasmic space (Jensen et al., 1980b; Fecycz \& Campbell, 1985). Evidence was presented suggesting that activation occurs by removal of a non-covalently bound inhibitory component during transport through the outer membrane. In the mutant strain PAO6204 the periplasmic elastase appears to be enzymically active. However, in some $P$. aeruginosa strains, e.g. PAO strains, proelastase is much more readily activated than in other strains. Thus, elastase in the PAO6204 mutant might have been spontaneously activated during sonication of the cells.

Proteins destinated for export are generally cleaved at the $\mathrm{NH}_{2}$-terminus during the transport process, probably during release from the cytoplasmic membrane (Blobel \& Dobberstein, $1975 a, b$; Silhavy et al., 1983). The molecular size of the periplasmic elastase from PAO6204 is the same as that of extracellular wild-type elastase, suggesting that export is blocked at a later stage in this mutant. The transposon insertion mutation with an easily selectable antibiotic resistance marker $\left(\mathrm{Tp}^{\mathrm{R}}\right)$ in the $x c p-1$ locus offers the possibility of cloning the gene(s) within this locus. The $x c p-1$ gene product then could be identified which should be helpful in elucidating the mechanism for protein export in $P$. aeruginosa. 
$P$. aeruginosa mutants with similar properties as those of PAO6204 but mapping in the $55 \mathrm{~min}$ region of the chromosome have recently been described (Wretlind \& Pavlovskis, 1983; A. Filloux et al., unpublished observation). In these mutants only active elastase and no proelastase could be detected in the periplasmic space. In some pleiotropic export mutants of Aeromonas hydrophila two outer membrane proteins are missing, while in others the outer membrane protein profile is normal (Howard \& Buckley, 1983). It will therefore be of interest to compare the outer membrane composition of the different $P$. aeruginosa mutants with that of the A. hydrophila mutants.

The only exoenzyme which we have found to be exported normally by the $x c p-1$ mutant is alkaline proteinase. Another transposon insertion mutant unable to produce extracellular alkaline proteinase has been described (Stapleton et al., 1984). The presence of cell-bound alkaline proteinase was not reported and neither was the genetic locus of the mutation in this case. It is clear however that the export of alkaline proteinase is different from that of other exoproteins in P. aeruginosa (Wretlind \& Pavlovskis, 1984).

PAO6202 and PAO6204 are isogenic except for the transposon insertion in $x c p-1$ in PAO6204 and in $h y u$ in PAO6202. Thus the effect of the $x c p-l$ mutation on virulence can be studied without the interference of other mutations. We could not find any significant difference in virulence between the two strains. This is in agreement with the results of Cryz et al (1983) who found that antisera against elastase and exotoxin A did not offer any protection against $P$. aeruginosa infection in a burned mouse model system. However, other investigators have found a small but significant role for exoproteins in this experimental infection model (Pavlovskis $e t$ al., 1977; Pavlovskis \& Wretlind, 1979). Our results concerning virulence must be interpreted with caution, since the mutant PAO6204 accumulates considerable exoenzyme activity in cellbound form. Cell-bound exoenzyme fractions may be released from dying cells and subsequently contribute to the virulence of the living mutant bacteria.

We thank D. Haas and M. Rella, Eidgenössische Technische Hochschule, Zürich, Switzerland, for providing strains for the study and S. J. Cryz, Jr, Swiss Serum and Vaccine Institute, Berne, Switzerland for screening the mutants. A. Hagelberg, K. Becker and I. Karlsson provided expert technical assistance. This work was supported by grants from the Swedish National Defence and from the Karolinska Institutets fonder.

\section{REFERENCES}

Björklind, A., Wretlind, B., Mölleg̊̊RD, I., Schad, P. A., Iglewski, B. H. \& CoX, C. D. (1985). Genetic mapping and characterization of Pseudomonas aeruginosa mutants that hyperproduce exoproteins. Journal of Bacteriology 162, 1329-1331.

Blobel, G. \& Dobberstein, B. (1975a). Transfer of proteins across membranes. I. Presence of proteolytically processed and unprocessed nascent immunoglobulin light chains on membrane-bound ribosomes of murine myeloma. Journal of Cell Biology 67, 835-851.

Blobel, G. \& Dobberstein, B. (1975b). Transfer of proteins across membranes. II. Reconstitution of functional rough microsomes from heterologous components. Journal of Cell Biology 67, 852-862.

Cheng, K.-J., Ingram, J. M. \& Costerton, J. W. (1971). Interactions of alkaline phosphatase and the cell wall of Pseudomonas aeruginosa. Journal of Bacteriology 107, 325-336.

Cryz, S. J., Fürer, E. \& Germanier, R. (1983). Protection against $P$ seudomonas aeruginosa infection in a murine burn wound sepsis model by passive transfer of antitoxin A, antielastase, and antilipopolysaccharide. Infection and Immunity 39, 10721079.

CuRTIS, R., III (1982). Gene transfer. In Manual of Methods for General Bacteriology, pp. 243-265.
Edited by P. Gerhardt, R. G. E. Murray, R. N. Costilow, E. W. Nester, W. A. Wood, N. R. Krieg \& G. B. Phillips. Washington, DC: American Society for Microbiology.

Davis, B. D. \& Mingioli, E. S. (1950). Mutants of Escherichia coli requiring methionine or vitamin $\mathbf{B}_{12}$. Journal of Bacteriology 60, 17-28.

FECYCZ, I. T. \& CAMPBELL, J. N. (1985). Mechanism of activation and secretion of a cell-associated precursor of an exocellular protease of Pseudomonas aeruginosa 34362A. European Journal of Biochemistry 146, 35-42.

HAAS, D. \& HollowaY, B. W. (1976). R factor variants with enhanced sex factor activity in Pseudomonas aeruginosa. Molecular and General Genetics 114, 243251.

haAs, D., Holloway, B. W., Schamböck, A. \& LEISINGER, T. (1977). The genetic organization of arginine biosynthesis in Pseudomonas aeruginosa. Molecular and General Genetics 154, 7-22.

HAAS, D., Cryz, S. J., ITOH, Y., LeISINGER, T., LuHTI, E., Mercenier, A., ReimmanN, C., Rella, M., Soldati, L., Watson, J. M. \& Wretlind, B. (1984). Some applications of transposon insertion mutagenesis in Pseudomonas. In Génétique des microorganismes industriels, pp. 91-111. Edited by $\mathrm{H}$. Heslot. Société Française de Microbiologie. 
Holloway, B. W. \& Matsumoto, H. (1984). Pseudomonas aeruginosa. Genetic Maps 3, 194-197.

Holloway, B. W., Krishnapillai, V. \& Morgan, A. F. (1979). Chromosomal genetics of Pseudomonas. Microbiological Reviews 43, 73-102.

HowARD, S. P. \& BUCKLEY, J. T. (1983). Intracellular accumulation of extracellular proteins by pleiotropic export mutants of Aeromonas hydrophila. Journal of Bacteriology 154, 413-418.

Jensen, S. E., Fecycz, I. T. \& Campbell, J. N. $(1980 a)$. Nutritional factors controlling exocellular protease production by Pseudomonas aeruginosa. Journal of Bacteriology 144, 844-847.

Jensen, S. E., Fecycz, I. T., Stemke, G. W. \& CAMPBELl, J. N. (1980 $b$ ). Demonstration of a cellassociated, inactive precursor of an exocellular protease. Canadian Journal of Microbiology 26, 8793.

Kreger, A. S. \& Gray, L. D. (1978). Purification of Pseudomonas aeruginosa proteases and microscopic characterization of pseudomonal protease-induced rabbit corneal damage. Infection and Immunity 19, 630-648.

LAURELL, C. B. (1966). Quantitative estimation of proteins by electrophoresis in agarose gels containing antibodies. Analytical Biochemistry 15, 45-52.

LIU, P. V. (1974). Extracellular toxins of Pseudomonas aeruginosa. Journal of Infectious Diseases 130, 594599.

MALAMY, M. H. \& HoReCKER, B. L. (1964). Release of alkaline phosphatase from cells of Escherichia coli upon lysozyme spheroplast formation. Biochemistry 3, 1889-1893.

Morgan, A. F. (1979). Transduction of Pseudomonas aeruginosa with a mutant of bacteriophage E79. Journal of Bacteriology 139, 137-140.

Neville, D. M., JR (1971). Molecular weight determination of protein-dodecyl sulfate complexes by gel electrophoresis in a discontinuous buffer system. Journal of Biological Chemistry 246, 6228-6334.

Pavlovskis, O. R. \& Wretlind, B. (1979). Assessment of protease (elastase) as a Pseudomonas aeruginosa virulence factor in experimental mouse burn infection. Infection and Immunity 24, 181-187.

Pavlovskis, O. R. \& Wretilnd, B. (1982). Pseudomonas aeruginosa toxins. In Medical Microbiology, vol. 1, pp. 97-128. Edited by C. S. F. Easmon \& J. Jeljaszewicz. London: Academic Press.

Pavlovskis, O. R., Pollack, M., Callahan, L. T., III
\& IGLewski, B. H. (1977). Passive protection by antitoxin in experimental Pseudomonas aeruginosa burn infection. Infection and Immunity 18, 596-602.

Pemberton, J. M. \& Holloway, B. W. (1972). Chromosome mapping in Pseudomonas aeruginosa. Genetical Research 19, 251-260.

Silhavy, T. J., Benson, S. A. \& EmR, S. D. (1983). Mechanisms of protein localization. Microbiological Reviews 47, 313-344.

Soldati, L., Crockett, R., Carrigan, J. M., LeISINGER, T., Holloway, B. W. \& HaAs, D. (1984). Revised location of the his $A$ and pru (proline utilization) genes on the Pseudomonas aeruginosa chromosome map. Molecular and General Genetics 193, 431-436.

Stapleton, M. J., JaGger, K. S. \& WarRen, R. L. (1984). Transposon mutagenesis of Pseudomonas aeruginosa exoprotease genes. Journal of Bacteriology 157, 7-12.

StIERITZ, D. D. \& Holder, I. A. (1975). Experimental studies of the pathogenesis of infections due to Pseudomonas aeruginosa: description of a burned mouse model. Journal of Infectious Diseases 131, 688691.

TORRIANI, A. (1968). Alkaline phosphatase of Escherichia coli. Methods in Enzymology 12B, 212-218.

Towbin, H., Staehelin, T. \& Gordon, J. (1979). Electrophoretic transfer of proteins from polyacrylamide gels to nitrocellulose sheets: procedure and some applications. Proceedings of the National Academy of Sciences of the United States of America 76, 4350-4354.

Woods, D. E. \& Iglewski, B. H. (1983). Toxins of Pseudomonas aeruginosa: new perspectives. Reviews of Infectious Diseases 5, supplement 4, S715-S722.

Wretlind, B. \& Pavlovskis, O. R. (1983). Pseudomonas aeruginosa elastase and its role in Pseudomonas infections. Reviews of Infectious Diseases 5, supplement 5, S998-S1004.

Wretlind, B. \& Pavlovskis, O. P. (1984). Genetic mapping and characterization of Pseudomonas aeruginosa mutants defective in the formation of extracellular proteins. Journal of Bacteriology 158, 801808.

WRETLIND, B., SJöBERG, L. \& WADSTRÖM, T. (1977). Protease deficient mutants of Pseudomonas aeruginosa: pleiotropic changes in activity of other extracellular enzymes. Journal of General Microbiology 103, 329-336. 